\title{
Utilization of Android-Based Interactive E-Modules
}

\author{
Ricu Sidiq ${ }^{1}$, Najuah ${ }^{2}$, Pristi Suhendro Lukitoyo ${ }^{3}$ \\ \{ricusidiq@unimed.ac.id ${ }^{1}$, Najuah@unimed.ac.id², Pristi@unimed.ac.id ${ }^{3}$ \} \\ ${ }^{1,2,3}$ Historical Education Study Program, Faculty of Social Sciences, Universitas Negeri Medan, Indonesia
}

\begin{abstract}
The purpose of this study was to determine the use of Android-based Interactive EModules in teaching and learning strategy courses. This research uses a descriptive quantitative design method that is exploratory with a questionnaire as a research instrument. The sample used in this study was 100from the Department of History Education in 2017. Data collection techniques in the form of questionnaires using the Likert Scale. Based on the results of data, it can be concluded that the level of satisfaction in the condition of being very satisfied with a total of $65.38 \%$, a condition of satisfaction $26 \%$, a condition that is quite satisfied at $7.5 \%$ and $1.12 \%$ dissatisfaction conditions were assessed in 8 (eight) e-learning characteristics, namely Non-linearity, Self-Managing, Feedback Interactivity, MultimediaLearners style, Just in Time, Dynamic Updating, Easy Access and Collaborative Learning.
\end{abstract}

Keywords: Android, .E-Modules, Interactive,

\section{Introduction}

The development of education must be able to answer the challenges of technological progress as a result of the current globalization, especially information and communication technology. Where advances in computer and internet technology and the variety of available software and hardware must be able to serve as opportunities for the world of education to improve the quality of learning. Mastery of information technology and education (ICT) in the field of education is very important to have to answer the challenges of global competition in this era of disruption. Higher education as the executor of the mandate of higher education must be more sensitive to all changes that occur in society. Where lecturers, students and even parents and graduates printed by universities are required to be able to adapt to facing all forms of change.

Therefore the Department of Historical Education, Faculty of Social Sciences, Universitas Negeri Medan encourages lecturers to innovate learning as a form of improving the quality of Indonesian human resources. Based on the survey, that in the world of education on campus is still using printed books as learning media. Teaching materials in the form of printed books still have limitations in the presentation of material. Besides, even though students have printed books, they often forget to bring them along. And if the situation occurs certainly it will not be good for learning. Printed books have some weaknesses in the manufacturing process, which are time- 
consuming, besides thick printed materials may be boring and kill students' interest to read them, if the binding and paper are bad, and printed materials will be easily damaged and torn. One alternative problem solving above is by developing teaching materials that can train students' independence in learning so that students can easily understand the learning material with what is seen in the form of text, images, audio, video, etc. that are electronic and interactive. In overcoming this problem used by lecturers by utilizing the Interactive E-Module.

The community is very fast in responding to technological advances, especially in the development of mass media, such as Facebook, Twitter, WhatsApp, and various other social media channels even without special training. Communities from various groups can communicate with social media. In the results of the study, it was explained that students spend 5-10 hours to access the internet and most of that time is used to access social media [1]. The Minister of Research in Technology and Higher Education (Menristek Dikti) in his remarks at the peak of the commemoration of the 2018 national education day stated that higher education in the future would offer many choices of learning models, ranging from Face to Face, Online Learning, to Blended Learning [2].

Seeing the needs of students and the demands of the times, a good learning strategy is to combine the best features of learning in the classroom (face to face) and e-learning to improve student learning outcomes. The choice of using an Android-based Interactive E-Module is appropriate in realizing this learning strategy. Where Android is an object-oriented programming language and can be run on all types of operating systems. As a programming language for internet and distributed applications, Android has several security mechanisms to guard applications, not used to damage the computer system that runs the application. Besides, it can be run on several computer operating systems, for example for mobile phones that have Java, Android, Windows, and Linux platforms. Based on this knowledge, the author is interested in conducting a study on the Utilization of an Android-based Interactive E-Module with quantitative descriptive research methods.

\section{Literature review}

The electronic module (e-module) itself is almost the same as an e-book. The difference is only in the contents of both [3]. In the module, of course, the content must include the elements that must be present in the module. While the e-book content is not limited to the elements contained in the module. Electronic modules are independent teaching materials that are arranged systematically into the smallest learning to achieve certain learning goals that are presented in electronic form that is Self Instruction, Self Contained, Stand Alone, Adaptive, and User-Friendly which contains one learning material. Electronic modules must be able to support an interactive learning process. Whereas if there is an interaction between lecturers and students.

Android or electronic-based interactive modules which are then better known as interactive EModules are teaching materials in the form of modules that are considered quite ideal to help students learn both for learning in the classroom and outside the classroom independently or in the guidance class [4]. Learning independence is given to students with the intention that students have the responsibility to regulate and discipline themselves and develop learning abilities on their own. 
Interactive teaching materials are creative, innovative and adaptive teaching materials for technological development and can make students happy and comfortable so that learning becomes effective and efficient [5]. Interactive teaching materials are needed to help students in independent learning. In learning requires a pleasant and empowering interaction. Fun and empowering can work by integrating the principles of education and entertainment (edutainment) [6] so that students feel entertained and do not feel easily bored in learning. This form of entertainment can be in the form of objects, equipment or forms of activities that make students feel happy doing learning activities.

Learning that uses information and communication technology can assist lecturers in delivering material and students in understanding the material being studied [5]. With multiproduct facility teaching materials including interactive e-modules, the material can be modified to be more interesting and make students more interested in learning. Interactive emodule teaching material is one of the teaching materials whose digital publishing process consists of text, images or a combination of both.

An interactive link with learning activities is the existence of a process of reciprocal relations between two individuals or individuals with a learning module. Based on the definitions mentioned, a learning module that has interactive criteria is if the module supports a reciprocal interaction/relationship with the user. Android is an operating system for Linux-based mobile devices that includes an operating system, middleware, and applications. Android is currently the operating system most widely used on mobile phones ranging from low end to high-end classes. Anyone can use this application with the help of a cellphone [7].

Android operation works with direct contact by the user, namely by giving a touch on the screen, the touch will be responded to quickly as if we touched on the surface of the water. Sometimes there are certain vibrations from the touch as a response given by the OS to its users. Gyroscope, proximity sensor, and accelerometer are some hardware as a complement to this OS that can respond to user actions [8]. Learning products can't be separated from world developments and learning needs. At present, it tends to require products that can be accessed anywhere and anytime. Product users have difficulty carrying a PC or laptop in several situations so that they need more portable devices such as mobile phones or gadgets to access information [9].

\section{Research method}

The research method used in this study is a quantitative descriptive exploratory method to describe the state or status of the phenomenon to answer the problem. This study describes how the level of student satisfaction in utilizing Android-based Interactive E-Modules. With operational research variables the use of interactive e-modules as learning media in 8 dimensions, namely Non-linearity, Self-Managing, Feedback interactivity, Multimedia-Leaners style, Just in Time, Dynamic Updating, Easy Accessibility and Collaborative Learning [10]. From these 8 dimensions, a questionnaire in the form of 24 questions was prepared as a research instrument. 


\section{Result and discussion}

Based on research that has been done, it can be stated that the Android-based Interactive EModule can be utilized in the History Education Department of the Faculty of Social Sciences, Medan State University. This is inseparable from the process of developing Interactive E-Modules that have been conducted by lecturers as lecturers before the Interactive E-Modules are utilized in the lecture process. After the lecture process is completed at the end of the semester, the lecturer evaluates the use of the Interactive E-Module as a learning medium.

Evaluation is done by giving a questionnaire of satisfaction to students with 8 (eight) characteristics of e-learning namely Non-linearity, Self-Managing, Feedback interactivity, Multimedia-Leaners style, Just in Time, Dynamic Updating, Easy Accessibility and Collaborative Learning [10]. For more clear about the results of how the use of interactive E-Modules in the department of history education can be clarified as follows.

The research data shows that the frequency distribution and the percentage of satisfaction levels in the use of Android-based Interactive E-Modules on non-linearity dimensions are presented in the following on the Table 1 below.

Table 1. Student Satisfaction Percent on the Non-linearity dimension

\begin{tabular}{lll}
\hline Distribution & F & Percent \\
\hline Very Satisfied & 67 & $67 \%$ \\
Satisfied & 24 & $24 \%$ \\
Quite Satisfied & 8 & $8 \%$ \\
Not Satisfied & 1 & $1 \%$ \\
Very Dissatisfied & 0 & 0 \\
\hline
\end{tabular}

The results of processing data on this dimension are the results presented in the following on the Table 2 below.

Table 2. Percent of student satisfaction with the Self-Managing dimension

\begin{tabular}{lll}
\hline Distribution & F & Percent \\
\hline Very Satisfied & 68 & $67 \%$ \\
Satisfied & 23 & $24 \%$ \\
Quite Satisfied & 8 & $8 \%$ \\
Not Satisfied & 1 & $1 \%$ \\
Very Dissatisfied & 0 & 0 \\
\hline
\end{tabular}

The level of satisfaction with the Feedback interactivity dimension is presented in the following on the Table 3 below. 
Table 3. Student Satisfaction Percent of Feedback interactivity dimensions

\begin{tabular}{lll}
\hline Distribution & F & Percent \\
\hline Very Satisfied & 67 & $67 \%$ \\
Satisfied & 25 & $25 \%$ \\
Quite Satisfied & 7 & $7 \%$ \\
Not Satisfied & 1 & $1 \%$ \\
Very Dissatisfied & 0 & 0 \\
\hline
\end{tabular}

The research data shows that frequency distribution and the Percent level of satisfaction in the use of Android-based Interactive E-Modules in the Multimedia-Leaners style dimensions are presented the following on the Table 4 below.

Table 4. Percent of student satisfaction with the Multimedia-Learners style dimension

\begin{tabular}{lll}
\hline Distribution & F & Percent \\
\hline Very Satisfied & $\mathbf{6 3}$ & $\mathbf{6 3 \%}$ \\
Satisfied & $\mathbf{2 8}$ & $\mathbf{2 8 \%}$ \\
Quite Satisfied & $\mathbf{8}$ & $\mathbf{8 \%}$ \\
Not Satisfied & $\mathbf{1}$ & $\mathbf{1 \%}$ \\
Very Dissatisfied & $\mathbf{0}$ & $\mathbf{0}$ \\
\hline
\end{tabular}

The percent level of student satisfaction in this dimension can be seen in the following Table 5 below.

Table 5. The percent of students' satisfaction towards the dimensions of just in Time

\begin{tabular}{lll}
\hline Distribution & F & Percent \\
\hline Very Satisfied & 65 & $65 \%$ \\
Satisfied & 26 & $26 \%$ \\
Quite Satisfied & 7 & $7 \%$ \\
Not Satisfied & 2 & $2 \%$ \\
Very Dissatisfied & 0 & 0 \\
\hline
\end{tabular}

The percent of satisfaction levels of students against this media from dynamic aspects of Updating can be seen from the following Table 6 below. 
Table 6. The percent of satisfaction of students against the dimensions of the Dynamic Updating

\begin{tabular}{lll}
\hline Distribution & F & Percent \\
\hline Very Satisfied & 60 & 71 \\
Satisfied & 29 & 20 \\
Quite Satisfied & 9 & 8 \\
Not Satisfied & 2 & 1 \\
Very Dissatisfied & 0 & 0 \\
\hline
\end{tabular}

From this aspect the level of satisfaction of students can be seen from the following Table 7 below.

Table 7. The Percent of satisfaction of students against the dimensions of the Easy Accessibility

\begin{tabular}{lll}
\hline Distribution & F & Percent \\
\hline Very Satisfied & 65 & $65 \%$ \\
Satisfied & 25 & $25 \%$ \\
Quite Satisfied & 9 & $9 \%$ \\
Not Satisfied & 1 & $1 \%$ \\
Very Dissatisfied & 0 & 0 \\
\hline
\end{tabular}

Research data show that from the aspect of collaborative learning and Percent distribution to get the results shown in the following Table 8 below.

Table 8. The percent of students' satisfaction with the dimensions of Collaborative Learning.

\begin{tabular}{lll}
\hline Distribution & F & Percent \\
\hline Very Satisfied & 68 & $68 \%$ \\
Satisfied & 28 & $28 \%$ \\
Quite Satisfied & 4 & $4 \%$ \\
Not Satisfied & 0 & 0 \\
Very Dissatisfied & 0 & 0 \\
\hline
\end{tabular}

Based on data on the level of student satisfaction in the use of Android-based Interactive EModules from the dimensions of Non-linearity, Self-Managing, Feedback Interactivity, Multimedia-Leaners style, Just in Time, Dynamic Updating, Easy Access and Collaborative Learning an analysis of the average percentage the level of satisfaction of students from the 8 dimensions that for the level of satisfaction is very satisfied conditions get an average percentage of $635.38 \%$. As for the condition of being satisfied with an average percentage of $26 \%$, and for a quite satisfying condition get an average percentage of $7.5 \%$ while for an unsatisfied condition get an average percentage of $1.12 \%$. This shows that the use of Android-based Interactive E-Modules in the Department of Historical Education can be said to be very satisfying. Based on the 
presentation of the results and discussion of the results of the study it can be concluded that the Android-based Interactive E-Module can be utilized in the History Education Department of the Faculty of Social Sciences, Medan State University with an average level of satisfaction at a very satisfying condition of $65.38 \%$, a satisfied condition of $26 \%$, the condition is quite satisfied by $7.5 \%$. And the condition is not satisfied by $1.12 \%$. This data shows the level of satisfaction from 8 dimensions of e-learning.

\section{References}

[1] N. Meilinda, P. I. Komunikasi, and I. Akademik, "Social Media On Campus :," J. Soc. Media, vol. 2, no. 1, pp. 53-64, (2018).

[2] M. Riset and D. A. N. P. Tinggi, "Sambutan pada puncak peringatan hari pendidikan nasional tahun 2018," (2018).

[3] N. Sunarya Herawati and A. Muhtadi, "Pengembangan Modul Elektronik (E-Modul) iNTERAKTIF Pada Mata Pelajaran Kimia Kelas XI SMA,” J. Inov. Pendidik., vol. 5, no. 2, pp. 180-191, (2018).

[4] Najuah, "Pengembangan Program Modul Interaktif Berbasis Komputer Matakuliah Statistik Dasar," J. Putri Hijau, vol. 2, no. 1, (2018).

[5] S. E. W. Zainal Abidin, "Pengembangan E-Modul Interaktif Berbasis Case ( Creative , Active ,Systematic, Effective) Sebagai Alternatif Media Pembelajaran Geometri Transpormasi Untuk Mendukung Kemandirian Belajar dan Kompetensi Mahasiswa," in Seminar Nasional Matematika dan Aplikasinya, 2017, pp. 197-202.

[6] Hamid, Mendesain Kegiatan Belajar-Mengajar Begitu Menghibur, Metode Edutainment Menjadikan Siswa Kreatif dan Nyaman. Yogyakarta: Divapress, (2012).

[7] W. Komputer, Membuat Aplikasi Komputer Tanpa Coding DENGAN app Inventor. Jakarta: PT. Gramedia, (2013).

[8] M. R. P. Ervian Arif Muhafid, "Pengembangan Alat Eksperimen Bunyi Dengan Sistem Akuisisi Data," J. Fis., vol. 4, no. 2, pp. 83-87, (2014).

[9] N. Suryani, A. Setiawan, and A. Putria, Media Pembelajaran Inovatif dan Pengembangannya. PT. Remaja Rosdakarya, (2018).

[10] M. Agustina, "Pemanfaatan E-Learning sebagai Media Pembelajaran," in Seminar Nasional Aplikasi Teknologi Informasi (SNATI), (2013), no. 12, pp. 8-12. 